Supporting Information For:

\title{
A Unimolecular G-Quadruplex that Functions as a Synthetic Transmembrane $\mathrm{Na}^{+}$Transporter
}

Mark S. Kaucher, William A. Harrell Jr. and Jeffery T. Davis*

*Corresponding author

Prof. Jeffery T. Davis

Department of Chemistry and Biochemistry

University of Maryland

College Park, MD 20742

Phone 301-405-1845

Fax 301-314-9121

e-mail: jdavis@umd.edu 
General experimental. The ${ }^{1} \mathrm{H}$ NMR spectra were recorded on a Bruker DRX-400 or Bruker Avance 400 operating at $400.13 \mathrm{MHz}$, or on a Bruker DRX-500 operating at $500.13 \mathrm{MHz}$. Chemical shifts are reported in ppm relative to the residual protonated solvent peak. Chromatography was performed using 60-200 mesh silica purchased from Baker and 40-120 $\mu$ Sephadex G-10 purchased from Pharmacia Fine Chemicals. Thin layer chromatography was performed on Kieselgel 60 F254 and Uniplate ${ }^{\mathrm{tm}}$ Silica Gel GF silica-coated glass plates and visualized by $\mathrm{UV}$ and $\mathrm{I}_{2}$. Deuterated solvents were purchased from Cambridge Iosotope Laboratories. Fast atom bombardment (FAB) mass spectra were recorded on a JEOL SX-102A magnetic sector mass spectrometer. ESI-MS experiments were recorded on a JOEL AccuTOF CS. All fluorimetric experiments were carried out on an Hitachi F4500 fluorescence spectrophotometer. The $\mathrm{pH}$ of solutions was monitored with a Fisher Scientific AR25 dual channel $\mathrm{pH} /$ ion meter. Circular dichroism (CD) spectra were recorded on a JASCO-810 spectropolarimeter with a $1 \mathrm{~cm}$ and $1 \mathrm{~mm}$ path length quartz cuvette. Deuterated solvents were purchased from Cambridge Isotope Laboratories. All chemicals andsolvents were purchased from Sigma, Fluka, or Aldrich. Adenosine derivative 4 (5'-t-butyldimethylsilyl-2',3'-isopropylidene adenosine), ${ }^{1}$ 3,5-(allyloxy)benzoic acid, ${ }^{2}$ and the potassium and sodium phenolates, ${ }^{3}$ were prepared following published methods. Liposomes were prepared by previously

published methods. ${ }^{4}$ High pressure extrusion was performed on the Avanti ${ }^{\mathrm{TM}}$ miniextruder with a $0.1 \mu \mathrm{m}$ or $0.2 \mu \mathrm{m}$ polycarbonate membrane. EYPC was purchased from Avanti Polar Lipids.

\section{Synthetic Procedures.}

3,5-bis(allyloxy) benzoic acid chloride: Thionyl chloride (10.93 $\mathrm{ml}, 56.3 \mathrm{mmol})$ was added to a solution of 3,5-bis(allyloxy) benzoic acid $(1.10 \mathrm{~g}, 4.7 \mathrm{mmol})$ in distilled toluene and the resulting mixture was refluxed for $2.5 \mathrm{~h}$. The solvent was evaporated under reduced pressure to give a green solid, which was immediately used without purification. 
5'-(3,5-bis(allyloxy)benzoyl)-2',3'-isopropylidene (G 1). To a solution of 2',3'-Oisopropylidene guanosine $\mathrm{s}^{3}(970 \mathrm{mg}, 3.0 \mathrm{mmol})$ and 4-dimethylaminopyridine $(10 \mathrm{mg})$ in distilled pyridine $(15 \mathrm{~mL})$ was added 3,5-bis(allyloxy) benzoyl acid chloride (1.10 g, 4.35 mmol). The resulting solution was stirred at $\mathrm{rt}$ under a $\mathrm{N}_{2}$ atmosphere for $4 \mathrm{~h}$. The solvent was evaporated under reduced pressure. The remaining white solid was dissolved in $\mathrm{CH}_{2} \mathrm{Cl}_{2}(100 \mathrm{~mL})$ and washed with $0.1 \mathrm{~N} \mathrm{HCl}(10 \mathrm{~mL})$, sat $\mathrm{NaHCO}_{3}(3 \times 10 \mathrm{~mL})$, and $\mathrm{H}_{2} \mathrm{O}(3 \times 10 \mathrm{~mL})$. After removal of the solvent, trituration with $i-\mathrm{Pr}_{2} \mathrm{O}$ gave a solid that was purified by flash chromatography $\left(5 \% \mathrm{MeOH}\right.$ in $\left.\mathrm{CH}_{2} \mathrm{Cl}_{2}\right)$ to give $\mathrm{G} \mathbf{1}(1.05 \mathrm{~g}, 72 \%)$. ${ }^{1} \mathrm{H}$ NMR (400 MHz, DMSO-d 6 ) ${ }^{*}: \delta 10.79$ (s, 1H, N1H), 7.82 (s, 1H, H8), 7.02 (d, 2H, H8', J = 2.3 Hz), 6.81 (t, 1H, H10', J = 2.3 Hz), 6.59 (bs, 2H,NH 2 ), 6.05 (s, 1H, H1'), 6.01 (ddt, 2H, H12', J = 17.3, 10.5, 5.0), 5.38 (ddd, 2H, H13', J = 17.3, 3.4, $1.0 \mathrm{~Hz}$ ), 5.25 (m, 1H, H3'), 5.25 (m, 1H, H2'), 5.25 (ddd, 2H, H13", J = 10.5, 3.4, 1.5 Hz), 4.59 (ddd, 4H, H11', J = 5.0, 1.5, 1.0 Hz), 4.42 (m, 2H, H5'), 4.40 (m, 1H, H4'), 1.52 (s, 3H, $\left.\mathrm{CH}_{3}\right), 1.32$ (s, $\left.3 \mathrm{H}, \mathrm{CH}_{3}\right) ;{ }^{13} \mathrm{C}$ NMR $\left(100 \mathrm{MHz}, \mathrm{DMSO}-\mathrm{d}_{6}\right): \delta 165.0,159.3,156.7,153.8,150.4$, 136.1, 133.4, 131.2, 117.7, 117.0, 113.3, 107.8, 106.6, 88.5, 84.3, 83.9, 81.2, 68.5, 65.0, 27.0, 25.3; HRMS (FAB) $[\mathrm{M}+\mathrm{H}]^{+}$calcd for $\mathrm{C}_{26} \mathrm{H}_{30} \mathrm{~N}_{5} \mathrm{O}_{8}$ 540.2094, found 540.2069.

* Resonances were assigned from a series of 2D COSY, NOESY, ${ }^{1} \mathrm{H}^{-13} \mathrm{C}$ HSQC, and ${ }^{1} \mathrm{H}-$ ${ }^{13} \mathrm{C}$ HMBC experiments. 


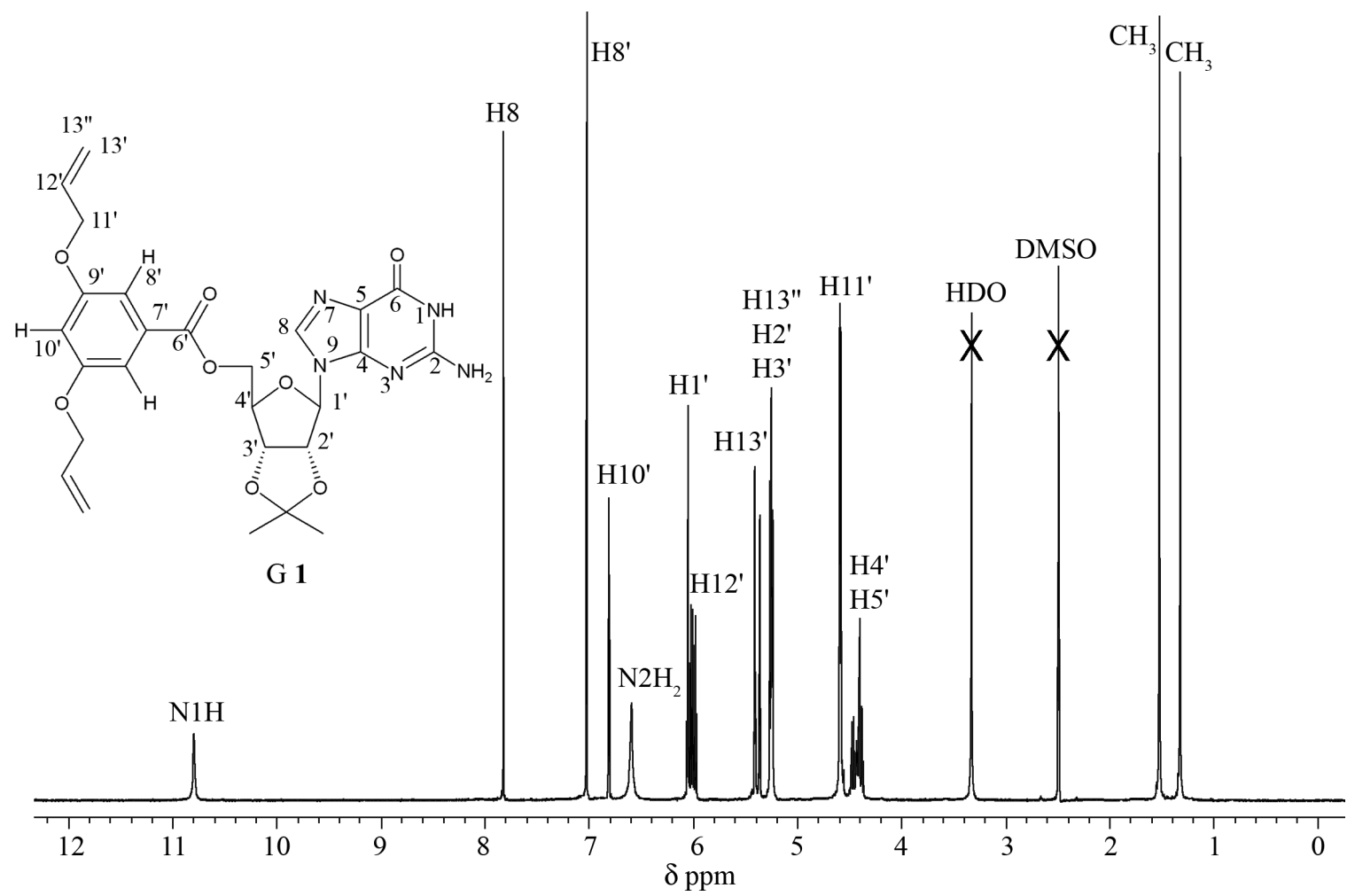

Figure S1. ${ }^{1} \mathrm{H}$ NMR spectrum $\left(\mathrm{DMSO}-\mathrm{d}_{6}\right)$ of G $\mathbf{1}$.

G-quadruplex 2 [G 1] $]_{16} \cdot \mathbf{4} \mathbf{K}^{+} \cdot \mathbf{4 D N P}$ : To a solution of G 1 (200 mg, $\left.0.37 \mathrm{mmol}\right)$ in $\mathrm{CH}_{2} \mathrm{Cl}_{2}(20 \mathrm{~mL})$ was added potassium 2,6-dinitrophenolate $\left(\mathrm{K}^{+} \mathrm{DNP}^{-}\right)(40 \mathrm{mg}, 0.18$ mmol). The resulting mixture was stirred at $\mathrm{rt}$ for $24 \mathrm{~h}$. After centrifuging, the organic layer was separated and concentrated to give an orange solid. The ${ }^{1} \mathrm{H}$ NMR spectrum in $\mathrm{CD}_{2} \mathrm{Cl}_{2}$ indicated that the G-quadruplex 2 had been generated. 


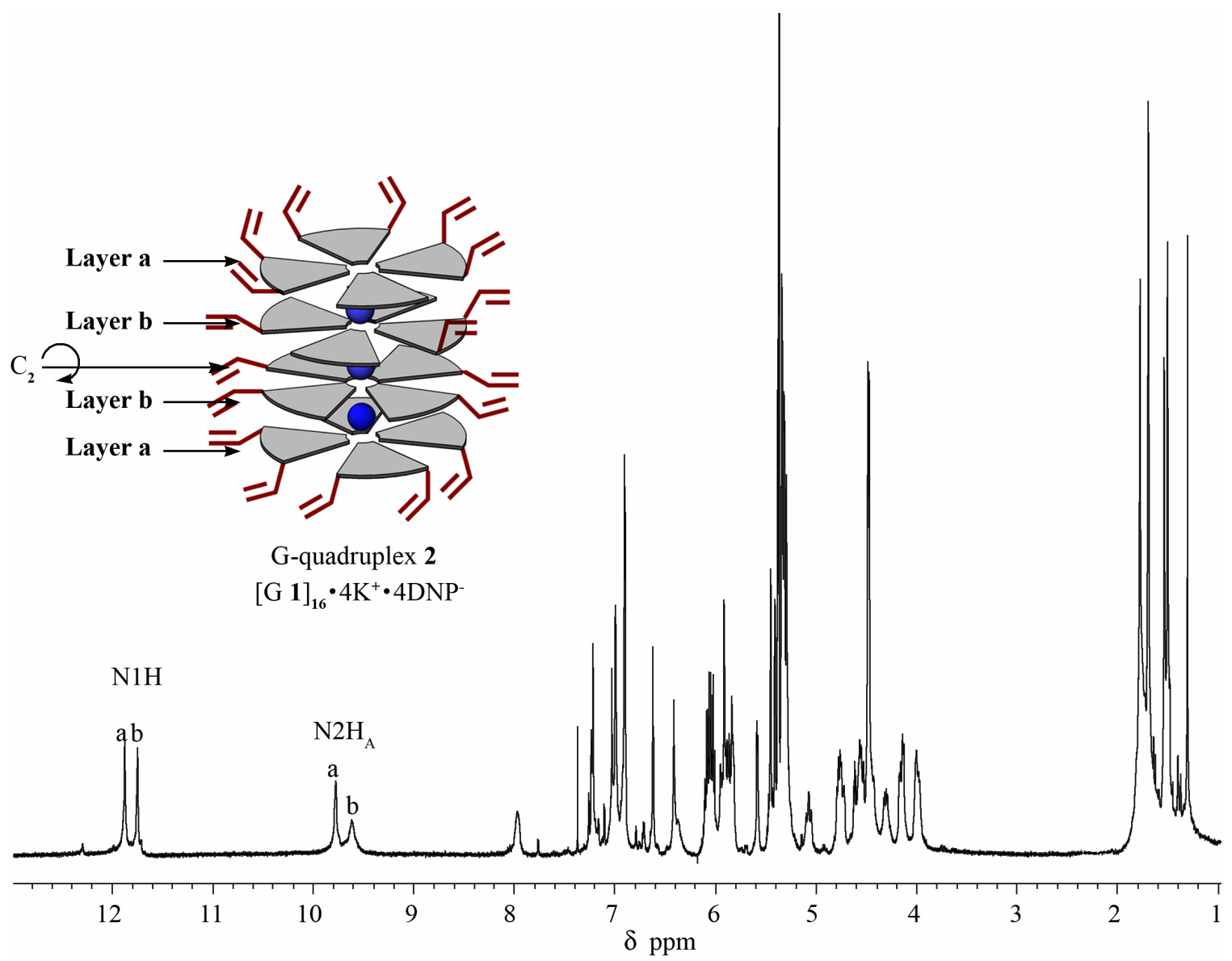

Figure S2. ${ }^{1} \mathrm{H}$ NMR spectrum $\left(\mathrm{CD}_{2} \mathrm{Cl}_{2}\right)$ of G-quadruplex $2,[\mathrm{G} 1] 16 \cdot 4 \mathrm{~K}^{+} \cdot 4 \mathrm{DNP}{ }^{-}$. The designations a (outside G-quartet layers) and b (inside G-quartet layers) refer to the 2 sets of signals observed for this $\mathrm{D}_{4}$-symmetric hexadecamer. 


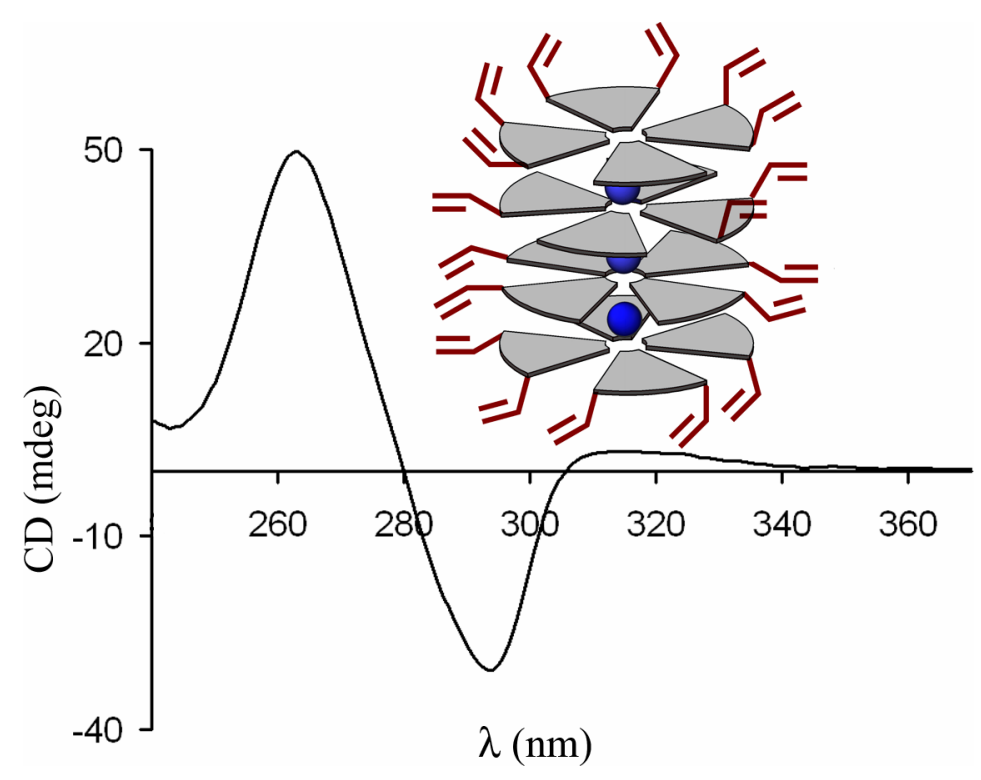

Figure S3. CD spectrum of G-quadruplex $2(0.171 \mathrm{mM})$ in $\mathrm{CH}_{2} \mathrm{Cl}_{2}$ using a $1.0 \mathrm{~cm}$ path length quartz cuvette. The positive $\mathrm{CD}$ band centered at $263 \mathrm{~nm}$ is characteristic of stacked $\mathrm{G}_{4}$-quartets within a chiral G-quadruplex. ${ }^{5}$

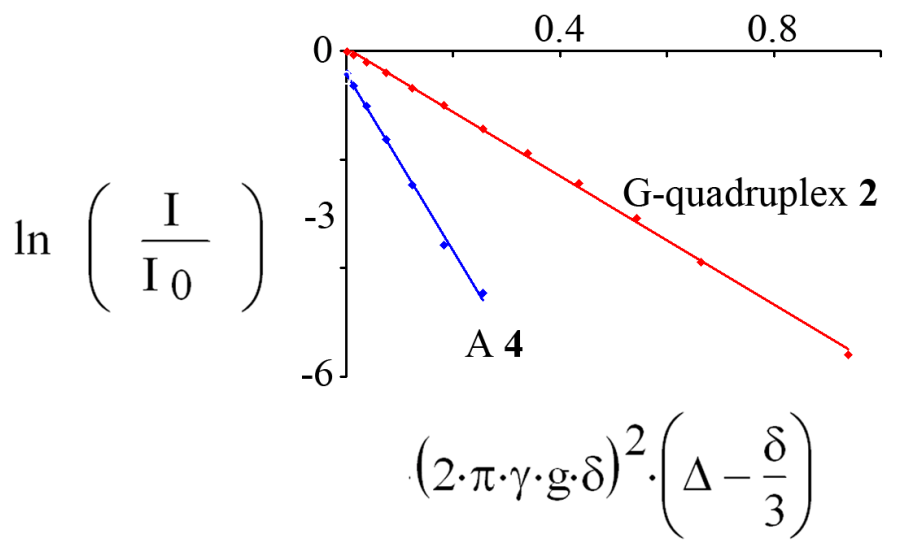

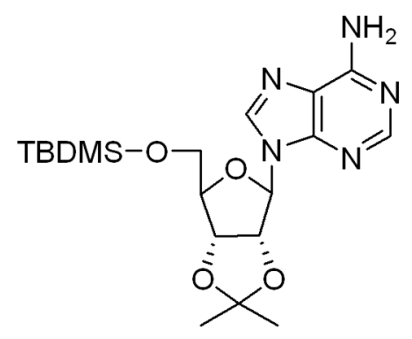

A 4

$\mathrm{D}_{\mathrm{s}}(4)=1.68 \times 10^{-9} \mathrm{~m}^{2} / \mathrm{s}$

$\mathrm{D}_{\mathrm{s}}(2)=5.57 \times 10^{-10} \mathrm{~m}^{2} / \mathrm{s}$

Experimental $\mathrm{D}_{\mathrm{s}}(\mathbf{2}) / \mathrm{D}_{\mathrm{s}}(\mathbf{4})=0.33$

Calculated $\mathrm{D}_{\mathrm{s}}(\mathbf{2}) / \mathrm{D}_{\mathrm{s}}(\mathbf{4})=0.35$

Figure S4. Diffusion NMR data for non-covalent G-quadruplex 2. Stejskal-Tanner plot of G-quadruplex 2 and $\mathrm{A} 4$ in $\mathrm{CD}_{2} \mathrm{Cl}_{2}$ at $21.8{ }^{\circ} \mathrm{C}$. For more details see the experimental in our previous paper on diffusion NMR on G-quadruplexes. ${ }^{6}$

G-quadruplex 3. To a solution of precursor G-quadruplex $2(80 \mathrm{mg}, 0.0068 \mathrm{mmol})$ in distilled, degassed $\mathrm{CH}_{2} \mathrm{Cl}_{2}(90 \mathrm{~mL})$ was added Grubb's second-generation catalyst $\left(\left(\mathrm{H}_{2} \mathrm{IMes}\right)\left(\mathrm{PCy}_{3}\right)\left(\mathrm{Cl}_{2}\right) \mathrm{Ru}=\mathrm{CHPh}\right)(9.3 \mathrm{mg}, 0.011 \mathrm{mmol}, 5 \mathrm{~mol} \%$ per alkene $){ }^{7}$ The resulting solution was stirred at $35^{\circ} \mathrm{C}$ under a $\mathrm{N}_{2}$ atmosphere for $48 \mathrm{~h}$. The resulting solution was then washed with $0.1 \mathrm{~N} \mathrm{HCl}(10 \mathrm{~mL})$, sat $\mathrm{NaHCO}_{3}(3 \times 10 \mathrm{~mL})$, and $\mathrm{H}_{2} \mathrm{O}(3$ $\mathrm{x} 10 \mathrm{~mL}$ ). After removal of the solvent, the black solid was purified by flash 
chromatography ( $5 \% \mathrm{MeOH}$ in $\mathrm{CH}_{2} \mathrm{Cl}_{2}$ ) to give G-quadruplex 3 as an off-white solid (32 mg, 57\%). ${ }^{1} \mathrm{H}$ NMR (400 MHz, DMSO-d 6 ): $\delta 10.78$ (bs, $\left.1 \mathrm{H}, \mathrm{N} 1 \mathrm{H}\right), 7.81(\mathrm{~s}, 1 \mathrm{H}, \mathrm{H} 8$ ), 6.88 (d, 2H, H8', J = 1.6 Hz), 6.65 (t, 1H, H10', J = 1.6 Hz), 6.60 (bs, 2H,NH $), 6.05$ (d, $1 \mathrm{H}, \mathrm{H1}$ ', J = 1.6 Hz), 5.71 (bs, 2H, H12'), $5.26\left(\mathrm{dd}, 1 \mathrm{H}, \mathrm{H} 2^{\prime}, \mathrm{J}=1.6,6.3 \mathrm{~Hz}\right.$ ), 5.22 (dd, 1H, H3', J = 3.0, 6.3 Hz), 4.73 (bs, 1H, H1 1'), 4.45-4.33 (m, 3H, H4', H5', H5"), 1.52 (s, $\left.3 \mathrm{H}, \mathrm{CH}_{3}\right), 1.32\left(\mathrm{~s}, 3 \mathrm{H}, \mathrm{CH}_{3}\right) ; \quad$ ESI-MS $[\mathrm{M}+3 \mathrm{~K}]^{3+}$ calcd for $\mathrm{C}_{384} \mathrm{H}_{400} \mathrm{~K}_{3} \mathrm{~N}_{80} \mathrm{O}_{128} 2766.5$, found. 2766.3 .

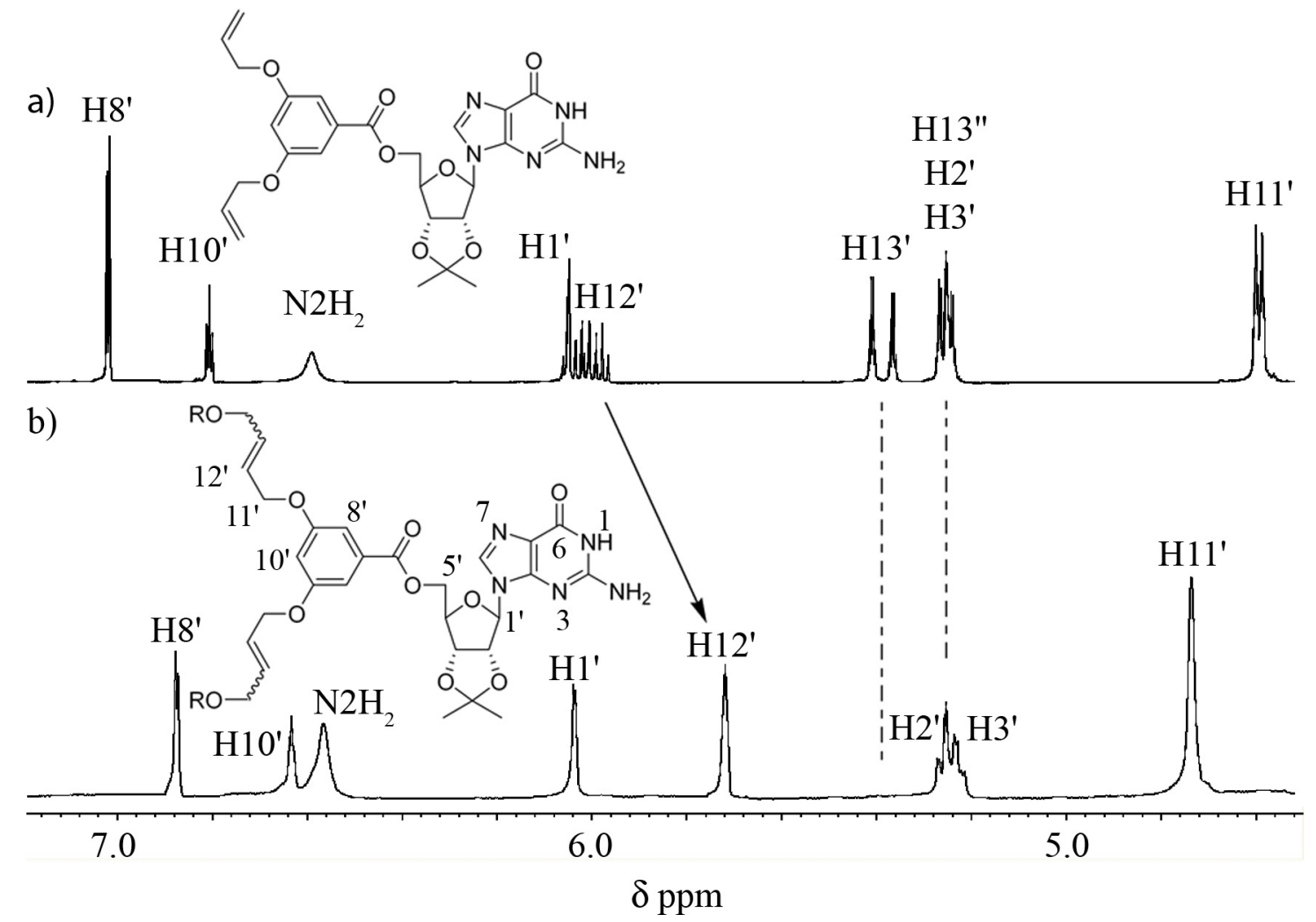

Figure S5. A region of the $400{ }^{1} \mathrm{H}$ NMR spectra (DMSO-d $\mathrm{d}_{6}$ ) with a) precursor G $\mathbf{1}$ and b) unimolecular G-quadruplex 3 . The asterisk and filled circle show the olefinic protons in $\mathrm{G} 1$ where metathesis occurs. The H12' peak at $5.71 \mathrm{ppm}$ is due to a cis/trans mixture. 


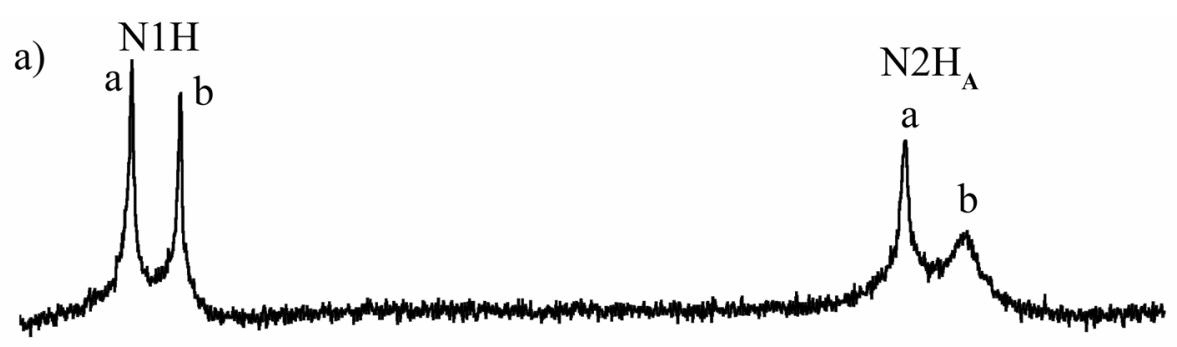

b)

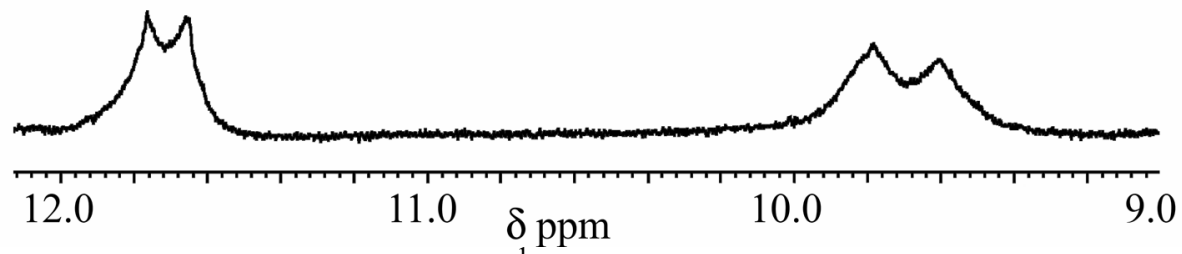

Figure S6. A region of the $400 \mathrm{MHz}{ }^{1} \mathrm{H}$ NMR spectra $\left(\mathrm{CD}_{2} \mathrm{Cl}_{2}\right)$ of a) precursor Gquadruplex 2 and b) unimolecular G-quadruplex 3. The spectra show the hydrogen bonded signals for the $\mathrm{N} 1 \mathrm{H}$ and $\mathrm{N}_{2} \mathrm{H}_{\mathrm{A}}$ inner and outer sets of signals observed for the two $\mathrm{D}_{4}$-symmetric hexadecamers.
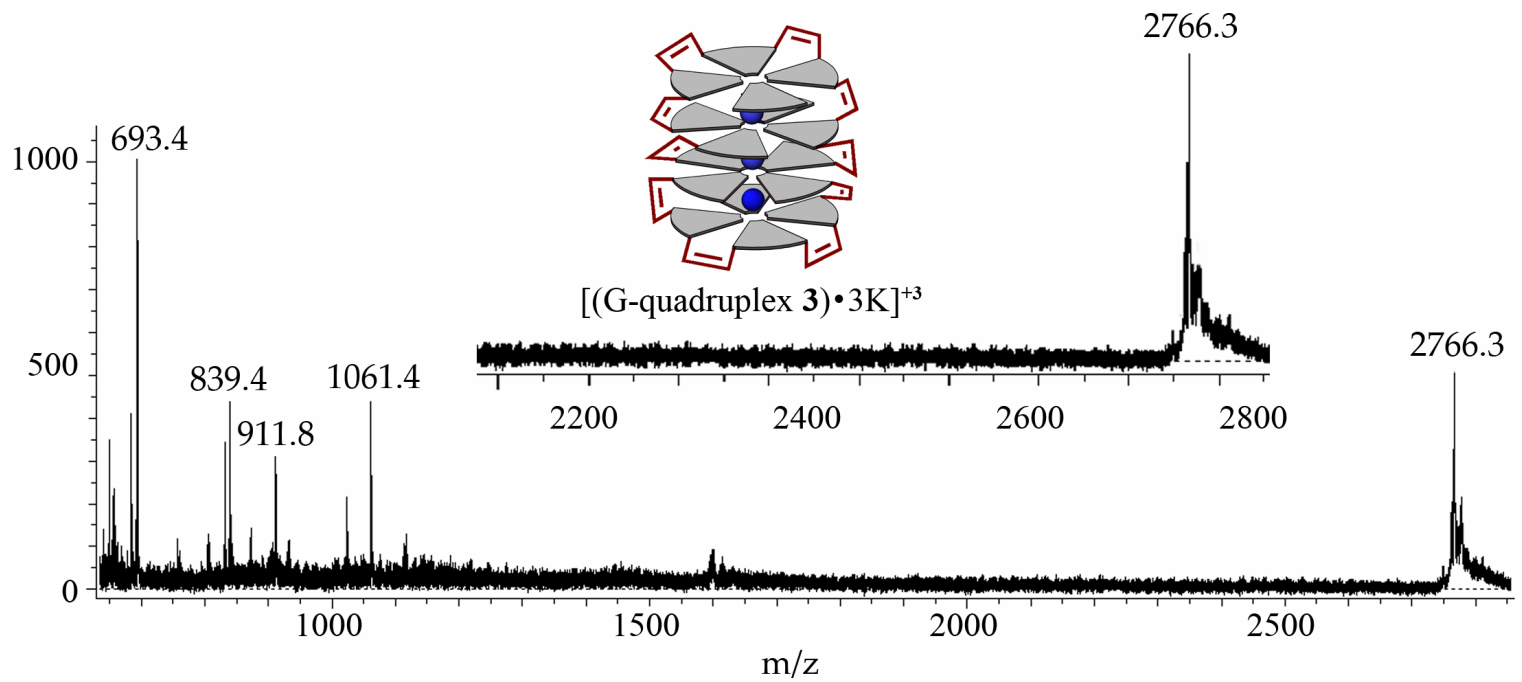

2766.3

Figure S7. ESI-MS of G-quadruplex 3 in 1:2 $\mathrm{H}_{2} \mathrm{O}-\mathrm{CH}_{3} \mathrm{CN}$ showing the triply charged

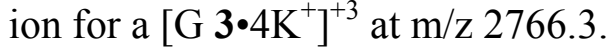




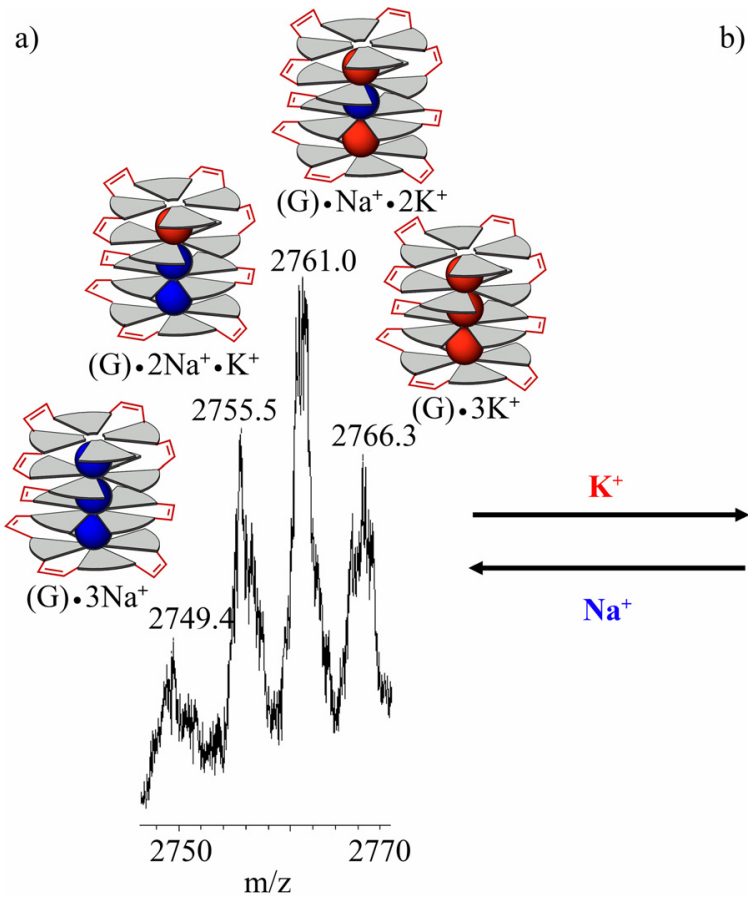

b)

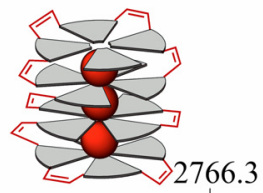

$(\mathrm{G}) \cdot 3 \mathrm{~K}^{+}$

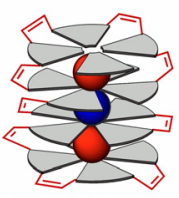

$(\mathrm{G}) \cdot \mathrm{Na}^{+} \cdot 2 \mathrm{~K}^{+}$
2761.0
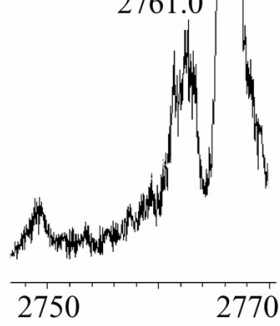

Figure S8. ESI-MS of G-quadruplex 3 in 1:2 $\mathrm{H}_{2} \mathrm{O}-\mathrm{CH}_{3} \mathrm{CN}$ of unimolecular Gquadruplex 3 a) after purification by flash chromatography and b) after washing with $\mathrm{K}(\mathrm{DNP})$. This change in the ESI-MS shows the ability to exchange cations in Gquadruplex 3 from $\mathrm{Na}$ to $\mathrm{K}$.

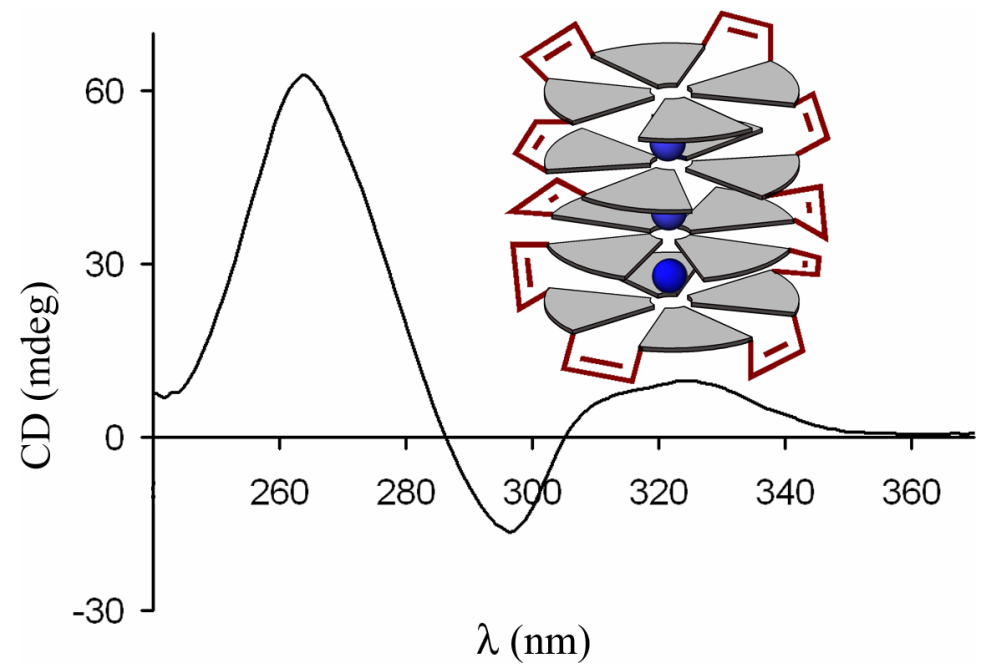

Figure S9. CD spectrum of unimolecular G-quadruplex $3(0.011 \mathrm{mM})$ in $\mathrm{CH}_{2} \mathrm{Cl}_{2}$ using a $1.0 \mathrm{~cm}$ path length quartz cuvette. The positive CD band centered at $264 \mathrm{~nm}$ is characteristic of stacked $\mathrm{G}_{4}$-quartets within a chiral G-quadruplex. ${ }^{5}$ 


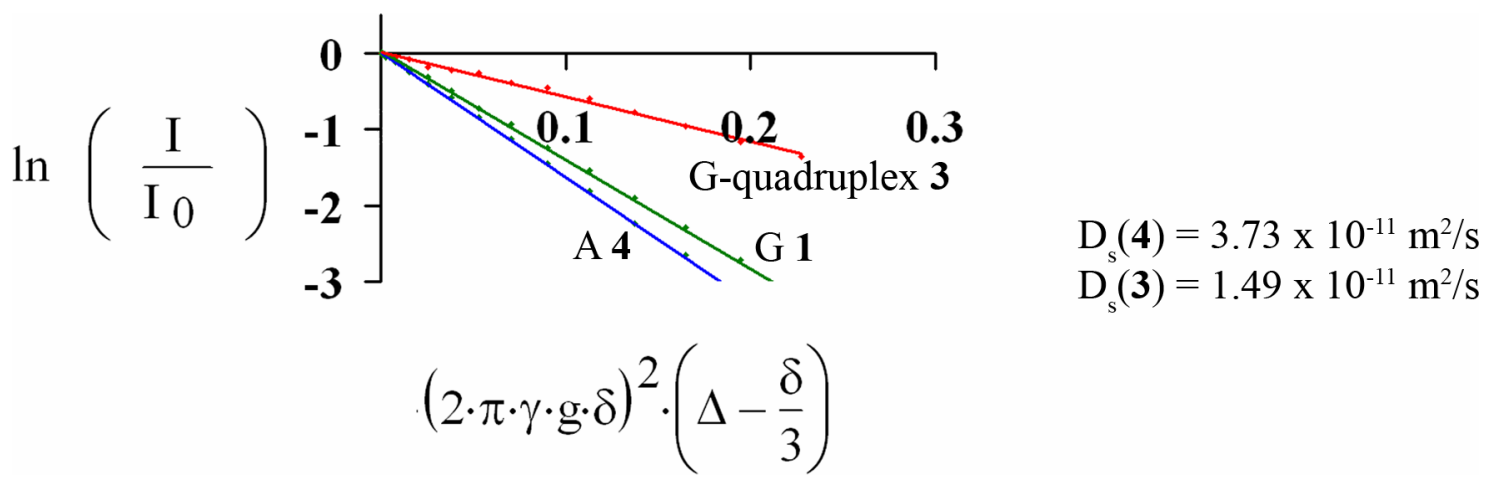

Figure S10. Diffusion NMR data for a unimolecular G-quadruplex 3. Stejskal-Tanner plot of G 1, G-quadruplex 3 and A 4 in hydrogen bonding disrupting solvent, DMSO-d 6 at $21.8{ }^{\circ} \mathrm{C}$. For more details see the experimental in our previous paper on diffusion NMR on G-quadruplexes. ${ }^{6}$

HPTS assay. ${ }^{4}$ HPTS (8-hydroxypyrene-1,3,6-trisulfonic acid) is a $\mathrm{pH}$ sensitive dye that can be monitored by fluorescence. HPTS-loaded vesicles (100 $\mu \mathrm{L}$ of the stock solution), filled with a saline phosphate buffer (10 mM sodium phosphate, $\left.\mathrm{pH} 6.4,75 \mathrm{mM} \mathrm{Na}_{2} \mathrm{SO}_{4}\right)$ were suspended in $1.9 \mathrm{~mL}$ of an corresponding phosphate sulfate buffer and placed into a fluorimetric cell. The emission of HPTS at $510 \mathrm{~nm}$ was monitored with excitation wavelengths at 403 and $460 \mathrm{~nm}$ simultaneously. During the experiment, $4 \mu \mathrm{L}$ of a 2.5 $\mathrm{mM}$ DMSO solution of the compound of interest was added (through an injection port), followed by injection of $20 \mu \mathrm{L}$ of $0.5 \mathrm{M}$ aqueous $\mathrm{NaOH}$. Addition of the $\mathrm{NaOH}$ resulted in a $\mathrm{pH}$ increase of approximately $1 \mathrm{pH}$ unit in the extravesicular buffer. Maximal possible changes in dye emission were obtained at the end of each experiment by lysis of the liposomes with detergent $(40 \mu \mathrm{L}$ of $5 \%$ aqueous Triton X100). The final transport trace was obtained as a ratio of the emission intensities monitored at 460 and $403 \mathrm{~nm}$ and normalized to $100 \%$ of transport.

${ }^{23}$ Na NMR experiments. ${ }^{8}$ Lithium filled vesicles $(250 \mu \mathrm{L}$ of the stock solution) containing phosphate buffer (10 mM lithium phosphate, $\mathrm{pH} 6.4,130 \mathrm{mM} \mathrm{LiCl})$ were suspended in $250 \mu \mathrm{L}$ of phosphate buffer $(10 \mathrm{mM}$ sodium phosphate, $\mathrm{pH} 6.4,100 \mathrm{mM}$ $\mathrm{NaCl}, 30 \mathrm{mM} \mathrm{Na} 5 \mathrm{PPP} i$ ). To this solution was added $2 \mu \mathrm{L}$ of $1 \mathrm{M} \mathrm{DyCl}_{3}$ (enough to shift extravescullar ${ }^{23} \mathrm{Na}$ peak upfield by $\sim 10 \mathrm{ppm}$ ). After monitoring vesicles by ${ }^{23} \mathrm{Na} \mathrm{NMR}$, 25-50 uL of compound (2.5 mM in DMSO) was added to the vesicles and the subsequent

${ }^{23} \mathrm{Na}$ NMR was taken 10 minutes later (508 scans). Spectra taken at $\mathrm{t}=15$ min and $\mathrm{t}=60$ min were identical to $\mathrm{t}=10 \mathrm{~min}$, ensuring that equilibrium had been achieved.

\section{References}

1) Davis, J. T.; Tirumala, S.; Jenssen, J. R; Radler, E.; Fabris, D. J. Org. Chem. 1995, 60, $4167-4176$.

2) Elmer, S. L.; Zimmerman, S. C. J. Org. Chem. 2004, 69, 7363-7366. 
3) Shi, X. D.; Mullaugh, K. M.; Fettinger, J. C.; Jiang, Y.; Hofstadler, S. A.; Davis, J. T. J. Am. Chem. Soc. 2003, 125, $10830-10841$.

4) Sidorov, V.; Kotch, F.W.; Kuebler, J.L.; Lam, Y.F.; Davis, J.T. J. Am. Chem. Soc. 2003, 125, 2840-2841.

5) G. Gottarelli, S. Masiero, G. P. Spada, Enantiomer 1998, 3, 429-436.

6) Kaucher, M. S.; Lam, Y. F.; Pieraccini, S.; Gottarelli, G.; Davis, J. T. Chem. Eur. J. 2004, 11, 164.

7) Scholl, M.; Ding, S.; Lee, C. W.; Grubbs, R. H. Org. Lett. 1999, 1, 953.

8) Pike, M.M.; Simon, S.R.; Balschi, J.A.; Springer, C.S. Proc. Natl. Acad. Sci. U.S.A. 1982, 79, 810. 